\title{
Protocols in Cleft Lip and Palate Treatment: Systematic Review
}

\author{
Pedro Ribeiro Soares de Ladeira ${ }^{1}$ and Nivaldo Alonso ${ }^{2,3}$ \\ ${ }^{1}$ School of Medicine, University of São Paulo, São Paulo, SP, Brazil \\ ${ }^{2}$ Division of Burns and Plastic Surgery, Department of Surgery, School of Medicine, University of São Paulo, São Paulo, SP, Brazil \\ ${ }^{3}$ Rua Afonso Brás, 473 cj 65 Vila Nova Conceição, 04511-000 São Paulo, SP, Brazil
}

Correspondence should be addressed to Nivaldo Alonso, nivalonso@gmail.com

Received 27 June 2012; Accepted 24 September 2012

Academic Editor: Renato Da Silva Freitas

Copyright ( $\odot 2012$ P. R. S. de Ladeira and N. Alonso. This is an open access article distributed under the Creative Commons Attribution License, which permits unrestricted use, distribution, and reproduction in any medium, provided the original work is properly cited.

Objectives. To find clinical decisions on cleft treatment based on randomized controlled trials (RCTs). Method. Searches were made in PubMed, Embase, and Cochrane Library on cleft lip and/or palate. From the 170 articles found in the searches, 28 were considered adequate to guide clinical practice. Results. A scarce number of RCTs were found approaching cleft treatment. The experimental clinical approaches analyzed in the 28 articles were infant orthopedics, rectal acetaminophen, palatal block with bupivacaine, infraorbital nerve block with bupivacaine, osteogenesis distraction, intravenous dexamethasone sodium phosphate, and alveoloplasty with bone morphogenetic protein-2 (BMP-2). Conclusions. Few randomized controlled trials were found approaching cleft treatment, and fewer related to surgical repair of this deformity. So there is a need for more multicenter collaborations, mainly on surgical area, to reduce the variety of treatment modalities and to ensure that the cleft patient receives an evidence-based clinical practice.

\section{Introduction}

Orofacial clefts are the most prevalent craniofacial birth defects and the second most common birth anomaly, second only to clubfoot [1]. In the United States of America, it is estimated that $\$ 100,000$ are spent to rehabilitate a child born with oral cleft [2].

The approach of the patient with cleft lip and palate is multidisciplinary, and the cleft team should be ideally composed by craniofacial surgeons, otolaryngologists, geneticists, anesthesiologists, speech-language pathologists, nutritionists, orthodontists, prosthodontists, and psychologists, and to be capable of treating even rare facial clefts with excellence, neurosurgeons, and ophthalmologists. In this manner, it is possible to provide long-term followup through the entire child's development and achieve all of the following treatment goals: normalized facial aesthetic, integrity of the primary and secondary palate, normal speech and hearing, airway patency, class I occlusion with normal masticatory function, good dental and periodontal health, and normal psychosocial development [3].
The most broadcast treatment modalities in the management of unilateral cleft lip and palate are listed in Table 1 (chronologic age) and Table 2 (dentofacial development).

The presented management of cleft lip and palate is not accepted exactly by all cleft centers, and there is a striking diversity of clinical practice in the area [4]. Evidence-based medicine should be the answer to the uncertainties in the treatment; however there is a paucity of high level of evidence (i.d. systematic reviews and randomized controlled trials [5]) on cleft lip and palate [6]. Therefore, many clinical decisions are made based on biased evidence, such as the decision of when to perform secondary bone graft, which is answered by many surgeons with the information of a retrospective study [7].

Aiming to find clinical decisions based on randomized controlled trials (RCTs), searches on cleft lip and/or palate were done in three main scientific databases: Cochrane Library, Embase, and PubMed [8]. Posteriorly, we selected articles that could validate or change the presented management. 
TABLE 1: Treatment modalities in the management of unilateral cleft lip and palate which are often based on chronologic age.

\begin{tabular}{ll}
\hline Timing & Procedure \\
\hline $\begin{array}{l}\text { After 16 weeks of } \\
\text { pregnancy }\end{array}$ & $\begin{array}{l}\text { Cleft lip diagnosis by ultrasound images } \\
\text { (palate is more difficult to acquire) [9] }\end{array}$ \\
& $\begin{array}{l}\text { Discussion with a craniofacial surgeon } \\
{[10]} \\
\text { Crenatal }\end{array}$ \\
& $\begin{array}{l}\text { Consultation with a } \\
\text { geneticist/dysmorphologist [10] }\end{array}$ \\
& $\begin{array}{l}\text { If the child has cleft palate, specialized } \\
\text { nipples and bottles are necessary to } \\
\text { improve feeding after birth [11] }\end{array}$ \\
Neonatal & $\begin{array}{l}\text { Cleft lip repair [12] } \\
\text { Cleft palate one-stage repair with } \\
\text { intravelar veloplasty [13] }\end{array}$ \\
6-12 months of age & Secondary rhinoplasty [14] \\
5 years &
\end{tabular}

TABLE 2: Treatment modalities in the management of unilateral cleft lip and palate which are often based on dentofacial development.

\begin{tabular}{|c|c|}
\hline Timing & Procedure \\
\hline Prior to cleft lip repair & Presurgical infant orthopedics [15] \\
\hline Primary dentition & $\begin{array}{l}\text { Orthodontic treatment for maxillary } \\
\text { expansion }[16]\end{array}$ \\
\hline Mixed dentition & $\begin{array}{l}\text { Orthodontic treatment for maxillary } \\
\text { expansion and maxillary protraction } \\
{[16]}\end{array}$ \\
\hline $\begin{array}{l}\text { Before eruption of } \\
\text { permanent dentition }\end{array}$ & $\begin{array}{l}\text { Secondary alveolar bone graft with } \\
\text { cancellous bone from iliac crest } \\
{[10,17]}\end{array}$ \\
\hline Permanent dentition & $\begin{array}{l}\text { Orthodontic treatment for dental } \\
\text { arches alignment [18] }\end{array}$ \\
\hline $\begin{array}{l}\text { After fully eruption of } \\
\text { permanent dentition, } \\
\text { dental arches alignment, } \\
\text { and end of the maxillofacial } \\
\text { growth }\end{array}$ & $\begin{array}{l}\text { Orthognathic surgery for maxillary } \\
\text { advancement [16] }\end{array}$ \\
\hline \multirow[t]{2}{*}{ After orthognathic surgery } & $\begin{array}{l}\text { Postsurgical orthodontics for closure } \\
\text { of residual spaces and occlusion final } \\
\text { adjustments [19] }\end{array}$ \\
\hline & $\begin{array}{l}\text { Replacement of missing teeth by a } \\
\text { prosthodontist [20] }\end{array}$ \\
\hline
\end{tabular}

\section{Methods}

On March 3, 2012, searches for RCTs were made in three databases (Cohrane Library, Embase, and PubMed) on cleft lip and/or palate. When appropriate, we used search strategies involving the MeSH descriptors and Emtree, Boolean logic operators, and free-text truncated with an asterisk.
The main descriptors used were as follows:

(i) MeSH: "cleft lip," "cleft palate";

(ii) Emtree: "cleft lip palate," "cleft lip," "cleft palate."

2.1. Cochrane Library. The searches in this database were made in "Search History," and the search strategy was assembled in "Search For."

We used MeSH descriptors when available, and free-text truncated with an asterisk. The following expression was added to the search strategy: "AND (randomized controlled trial*):ti,ab,kw." Only the results in "Cochrane Central Register of Controlled Trials" were considered.

2.2. Embase. The searches in this database were made in "Advanced Search," selecting the following items: "Map to preferred terminology (with spell check)," "Also search as free text," and "Include sub-terms/derivatives." In "Records from," we selected only "Embase."

We used Emtree descriptors and selected the item "Randomized Controlled Trial" in "Advanced Limits," option "Evidence Based Medicine."

2.3. PubMed. The searches in this database were made in "Search details."

We used $\mathrm{MeSH}$ descriptors when available, and freetext truncated with an asterisk. Additionally, we selected "Randomized Controlled Trial" in "Limits," option "Type of Article."

All abstracts provided by the databases in the searches were collected, resulting in a total of 170 different articles. From these abstracts, studies that clearly were not RCTs (e.g., reviews and case series) or not focused on cleft treatment were excluded. As a result, we were left with 88 papers. Posteriorly, we searched "Portal de Periódicos da CAPES" (http://www.capes.gov.br/) for the full-text articles. After meticulous reading of the studies, we verified that 53 of the 88 articles were really RCTs. Next, the approaches compared in each study were analyzed, in order to select articles in which the comparisons discussed appeared in two or more of the 53 studies. At the end of the selection, 28 articles were included for the analysis of the obtained conclusions. One paper on infant orthopedics was excluded since it emphasized a methodological fault on the study design (i.d. sample heterogeneity). The flowchart below (Figure 1) outlines the process of articles selection.

\section{Results}

The search results were recorded in Figure 2.

The issues discussed by the 28 selected articles were as follows:

(i) infant orthopedics: $15 / 28=53.57 \%$;

(ii) postoperative pain relief: $5 / 28=17.86 \%$;

(iii) management of the cleft maxillary hypoplasia: $4 / 28=$ $14.28 \%$;

(iv) perioperative steroids: $2 / 28=7.14 \%$;

(v) alveoloplasty: $2 / 28=7.14 \%$. 


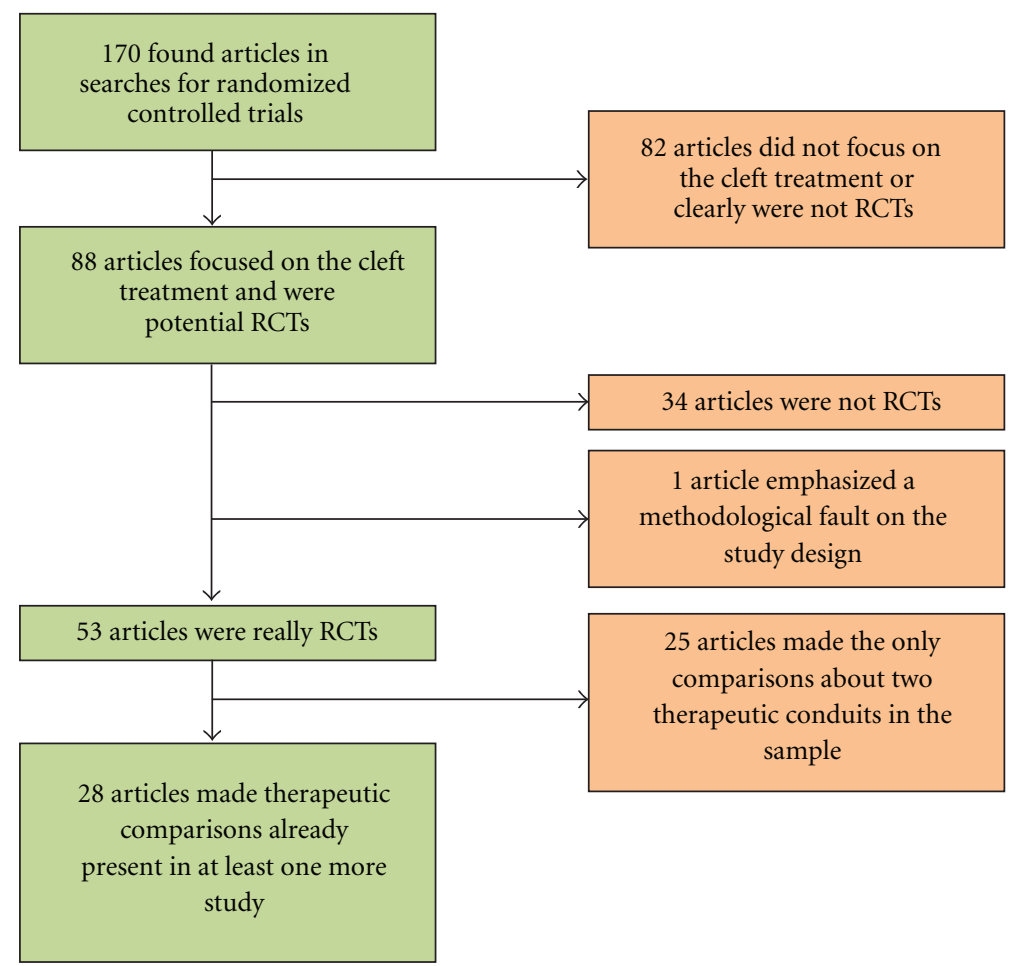

FIGURE 1: Flowchart outlining the selection process of the 28 articles.

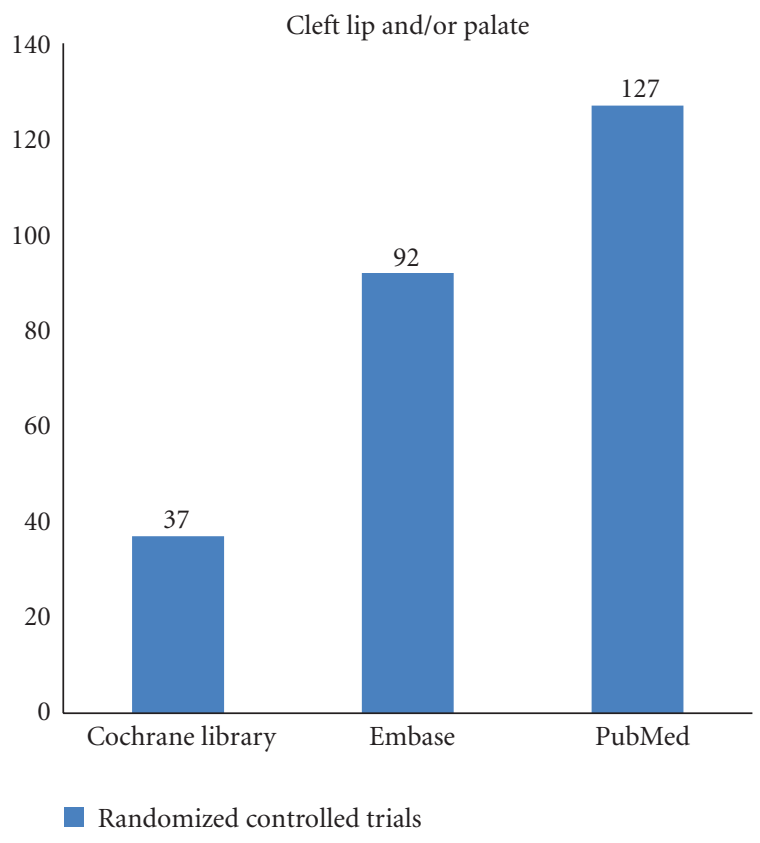

Figure 2: Results of searches on "Cleft Lip and/or Palate" in the three databases.

The conclusions of the 28 papers are presented by issue addressed in Tables 3, 4, 5, 6, and 7, where the signs " $<$," ">," and "=" mean, respectively, that experimental approach is "less recommended than," "more recommended than," and "equivalent to" control.

\section{Discussion}

RCTs and systematic reviews of these studies are considered the best levels of evidence to conduct clinical practice [49]. For this reason, we searched for RCTs that could orientate the cleft lip and/or palate treatment, which is marked by a great number of approaches [10]. To find the RCTs we used two main databases proposed by World Health Organization (i.d. PubMed and Embase) [8] and the Cochrane Library, reference of studies for evidence-based medicine practice [50]. Therefore, from the 170 articles found in the searches for RCTs, we reached 28 final studies that approached therapeutic practices on cleft patient. The issues of these 28 articles were collected together with their conclusions.

During this study, a scarce number of RCTs were found approaching cleft treatment. This fact is confirmed by the literature, which showed in 2004 that only 6\% of RCTs in "Plastic and Reconstructive Surgery," "British Journal of Plastic Surgery," and "Annals of Plastic Surgery" approached cleft lip and/or palate [51]. In an article of 2007, it is possible to observe that the lack of studies with high level of evidence is a problem present in the whole plastic surgery, resulting in the following distribution of articles from the 16 leading journals in the area: case report, $80 \%$; RCTs, $2 \%$; and metaanalysis, $<1 \%$ [52].

In the final sample of 28 articles, we verified the presence of five issues, arranged here in descending order by number of studies that addressed them: infant orthopedics, postoperative pain relief, management of the cleft maxillary hypoplasia, and perioperative steroids and alveoloplasty. The issues of the selected articles are consistent with 
TABLE 3: Conclusions of articles that addressed "infant orthopedics".

\begin{tabular}{|c|c|c|c|}
\hline \multicolumn{4}{|c|}{ Infant Orthopedics } \\
\hline Experimental group & Conclusion & Control & Explanation for the conclusion \\
\hline $\begin{array}{l}\text { Patients who had } \\
\text { infant orthopedics }\end{array}$ & $=$ & $\begin{array}{l}\text { Patients who did not } \\
\text { have infant orthopedics }\end{array}$ & $\begin{array}{l}\text { Cephalometric outcomes at ages } 4 \text { and } 6 \text { were not } \\
\text { relevant }[21] \text {; no long-term (age } 6[22] \text { ) or short-term } \\
\text { (18 months [23]) outcomes on facial appearance; no } \\
\text { influence on mother's satisfaction }[24] \text {; no } \\
\text { improvement on feeding efficiency or general body } \\
\text { growth within the first year }[25,26] \text {; no long-term } \\
\text { outcomes on the maxillary arch dimensions (age } 6 \\
\text { [27]), on deciduous dentition (age } 6[27,28] \text { ), or on } \\
\text { the occlusion (age } 6[28]) \text {; no short-term outcomes on } \\
\text { the maxillary arch dimensions (18 months) }[29,30] \text {; no } \\
\text { long-term outcomes on language development (age } 6) \\
{[31] \text {; no improvement on the intelligibility at } 2.5 \text { years }} \\
\text { [32]. }\end{array}$ \\
\hline $\begin{array}{l}\text { Patients who had } \\
\text { infant orthopedics }\end{array}$ & $>$ & $\begin{array}{l}\text { Patients who did not } \\
\text { have infant orthopedics }\end{array}$ & $\begin{array}{l}\text { Acceptable cost effectiveness based on speech } \\
\text { development at } 2.5 \text { years [33]; better speech } \\
\text { development between } 2 \text { and } 3 \text { years [34]; higher ratings } \\
\text { for intelligibility at } 2.5 \text { years [35]. }\end{array}$ \\
\hline
\end{tabular}

TABLE 4: Conclusions of articles that addressed "postoperative pain relief".

\begin{tabular}{|c|c|c|c|}
\hline \multicolumn{4}{|c|}{ Postoperative pain relief* } \\
\hline Experimental group & Conclusion & Control & Explanation for the conclusion \\
\hline Rectal Acetaminophen & $>$ & Rectal placebo & $\begin{array}{l}\text { In children who underwent palatoplasty, } \\
\text { acetaminophen ( } 40 \mathrm{mg} / \mathrm{kg} \text { administered in the } \\
\text { operating room at the end of surgery, and } 30 \mathrm{mg} / \mathrm{kg} \\
\text { every } 8 \text { hours until } 48 \text { hours) was more effective in pain } \\
\text { control than placebo [36]. }\end{array}$ \\
\hline $\begin{array}{l}\text { Rectal Acetaminophen } \\
(40 \mathrm{mg} / \mathrm{kg})\end{array}$ & $=$ & Rectal placebo & $\begin{array}{l}\text { Acetaminophen and placebo were equivalents in } \\
\text { regards to nauseas and vomits, the most frequent } \\
\text { adverse effects [36]. Rectal acetaminophen } \\
\text { (administered at anesthesia induction) did not result in } \\
\text { analgesic plasma concentrations and it was not effective } \\
\text { in pain control after palatoplasties [37]. }\end{array}$ \\
\hline $\begin{array}{l}\text { Bilateral Palatal Block with } \\
\text { Bupivacaine }(0.5 \mathrm{~mL} \text { of } 0.25 \% \\
\text { solution at greater palatine, lesser } \\
\text { palatine, and nasopalatine } \\
\text { foramina) }\end{array}$ & $=$ & $\begin{array}{l}\text { Plain saline }(0.5 \mathrm{~mL} \text { at } \\
\text { each point })\end{array}$ & $\begin{array}{l}\text { Bupivacaine and saline were effective in the palatal } \\
\text { block and provided good parental satisfaction. Both } \\
\text { provided better postoperative analgesia than the no } \\
\text { block group [38]. }\end{array}$ \\
\hline $\begin{array}{l}\text { Bilateral Infraorbital Nerve Block } \\
\text { with Bupivacaine }\end{array}$ & $>$ & Plain saline & $\begin{array}{l}\text { In children who underwent cleft lip repair, the injection } \\
\text { of } 1.5 \mathrm{~mL} \text { of } 0.25 \% \text { bupivacaine (extra-oral approach) } \\
\text { [39] or } 1-1.5 \mathrm{~mL} \text { of } 0.5 \% \text { bupivacaine (intraoral } \\
\text { approach) [40] in the area of } \\
\text { infraorbital foramen provided safe and prolonged } \\
\text { postoperative pain relief (at least } 8 \text { hours [39]). }\end{array}$ \\
\hline
\end{tabular}

* All the alveoloplasties used iliac crest bone graft.

TABLE 5: Conclusions of articles that addressed "management of the cleft maxillary hypoplasia".

\begin{tabular}{|c|c|c|c|}
\hline \multicolumn{4}{|c|}{ Management of the cleft maxillary hypoplasia } \\
\hline Experimental group & Conclusion & Control & Explanation for the conclusion \\
\hline Osteogenesis distraction & $=$ & Le Fort I osteotomy & $\begin{array}{l}\text { No significant differences were found in development } \\
\text { of velopharyngeal insufficiency postoperatively [41, 42] } \\
\text { and patient morbidity (infection and occlusion } \\
\text { disturbance) [43]. }\end{array}$ \\
\hline Osteogenesis distraction & $>$ & Le Fort I osteotomy & $\begin{array}{l}\text { Better skeletal stability in maintaining the maxillary } \\
\text { advancement in the long term }[43,44] .\end{array}$ \\
\hline
\end{tabular}


TABLE 6: Conclusions of articles that addressed "perioperative steroids".

\begin{tabular}{|c|c|c|c|}
\hline \multicolumn{4}{|c|}{ Perioperative steroids } \\
\hline Experimental group & Conclusion & Control & Explanation for the conclusion \\
\hline $\begin{array}{l}\text { Intravenous dexamethasone } \\
\text { sodium phosphate }\end{array}$ & $>$ & $\begin{array}{l}\text { Intravenous dextrose } \\
\text { solution }\end{array}$ & $\begin{array}{l}\text { In patients who underwent primary palatoplasty, } \\
\text { intravenous dexamethasone sodium phosphate } \\
0.25 \mathrm{mg} / \mathrm{kg} \text { before surgery and every } 8 \text { hours (two doses } \\
\text { after surgery) lowered the risks of postoperative airway } \\
\text { distress and fever [ } 45] \text {, and no adverse sequelae were } \\
\text { verified [46]. }\end{array}$ \\
\hline
\end{tabular}

TABLE 7: Conclusions of articles that addressed "alveoloplasty".

\begin{tabular}{|c|c|c|c|}
\hline \multicolumn{4}{|c|}{ Alveoloplasty } \\
\hline Experimental group & Conclusion & Control & Explanation for the conclusion \\
\hline $\begin{array}{l}\text { Cleft repair with BMP-2 (bone } \\
\text { morphogenetic protein-2) }\end{array}$ & $>$ & Iliac crest bone graft & $\begin{array}{l}\text { Increased bone regeneration and lower patient } \\
\text { morbidity: oral wound quality, pain, infection, } \\
\text { paresthesia, and donor area wound healing } \\
\text { [47]; infection, paresthesia, neuropathy, and } \\
\text { donor area wound healing [48]. }\end{array}$ \\
\hline
\end{tabular}

the importance given by the literature, because of the following: the infant orthopedics efficacy is debatable since its creation, nearly six decades ago $[53,54]$; postoperative pain relief for children has become a necessary practice recently, about two decades ago, on account of several myths on pediatric pain and lack of scientific knowledge in the area [55]; the question whether to use or not osteogenesis distraction instead of the conventional Le Fort I osteotomy on cleft maxillary hypoplasia divides opinions in the scientific community $[56,57]$; perioperative steroids are a common practice in craniofacial surgery; however it has several documented side effects $[58,59]$ and few well designed studies [46]; alveoloplasty is a highly debated intervention, especially with the advent of bone substitutes [60].

From the five issues, only two approached the surgical act, resulting in $21.43 \%(6 / 28)$ of the selected articles. This fact reflects the lack of RCTs on surgical procedures itself. A survey of 2003 supports this affirmation, which estimates that only $3.4 \%$ of the publications on the main surgical journals were RCTs [61].

From the final sample, $53.57 \%$ were composed by articles approaching infant orthopedics. That was due to the fact that 14 of the 15 studies on this issue were part of the Dutch Intercenter Study (Dutchcleft), a great effort to analyze the effects of presurgical infant orthopedic treatment in complete unilateral cleft lip and palate [32].

No study in the selected sample analyzed specifically a cleft patient with a syndrome or congenital abnormality. That explains the difficulty of treating orofacial clefts related to over 300 syndromes [62], and the twenty percent of all children with a cleft that have other congenital abnormality, part of a known syndrome or not [63].

From the 15 studies approaching infant orthopedics, only 3 found a benefit of this treatment, an improvement of the patient speech at nearly 2.5 years old [33-35]. However, when the language development was evaluated in the long term, at nearly 6 years old, there were no differences between experimental group and control [31]. On the other hand, all of the 14 Dutchcleft studies used only the Zurich approach to treat their patients whereas the other articles applied a passive and an active maxillary orthopedic treatment. So, in our systematic review we did not find RCTs about nasoalveolar molding therapy, a promising practice in presurgical infant orthopedics [54]. Non-RCTs studies have been appointing to the benefits of nasoalveolar molding therapy: long-term aesthetic outcomes [64-66] and better nasal symmetry [67].

Four distinct comparisons were found on postoperative pain relief: rectal acetaminophen versus placebo, bilateral nerve block with bupivacaine versus plain saline, continuous bupivacaine infusion through iliac crest catheter versus plain saline, and intravenous ketorolac with morphine versus morphine alone. There was a divergence between the conclusions of the two RCTs found on the first comparison; one appointed an effective pain control and equivalence in regards to nauseas and vomits (rectal loading dose of $40 \mathrm{mg} / \mathrm{kg}$ followed by $30 \mathrm{mg} / \mathrm{kg} 8$ hourly) [36], whereas the other one did not observe effective pain control (single prophylactic dose of $40 \mathrm{mg} / \mathrm{kg}$ ) [37], emphasizing the fact that both analyzed palatoplasties. These results are in concordance with the standard clinical practice that states a postoperative rectal loading dose (30-40 mg/kg) followed by regular maintenance doses $(20 \mathrm{mg} / \mathrm{kg} 6$ hourly or $30 \mathrm{mg} / \mathrm{kg}$ 8 hourly) [68-70]. Besides the difficulties associated with rectal administration (e.g., delayed and erratic absorption), an RCT done in patients undergoing craniosynostosis repair verified a higher efficacy than oral administration [68].

On the comparison of bilateral nerve block with bupivacaine versus plain saline, there were one article approaching palatal block [38] and two approaching infraorbital nerve block [39, 40]. Prabhu et al. proved with a randomized, double blind, prospective clinical trial that bilateral infraorbital nerve block with bupivacaine is more effective than periincisional infiltration in postoperative pain relief after cleft lip repair [71], and it became a standard clinical practice in cleft care [72, 73]. However, the scientific literature does not clarify which volume should be used to make this block, 
so there is evidence defending $0.5 \mathrm{~mL}$ of $0.5 \%$ bupivacaine in each side [74], $3 \mathrm{~mL}$ of $0.5 \%$ bupivacaine [75], and $0.5-1 \mathrm{ml}$ of $0.5 \%$ bupivacaine [73]. Since very small doses of bupivacaine have serious side effects, such as cardiac dysrhythmias and neurotoxicity [76], more studies need to be done to standardize this technique. In regards to the article that analyzed palatal block, there were no differences between experimental group $(0.5 \mathrm{~mL}$ of $0.25 \%$ bupivacaine at each point) and control ( $0.5 \mathrm{~mL}$ of plain saline at each point), with both resulting in postoperative analgesia. Besides the extensive use of palatal block [77], including in Smile Train [78], the results of the selected RCT led us to conclude that the analgesic effects are results from the liquid pressure, not from the anesthetic solution. Such results appeared in a similar manner with Van Gheluwe and Walton, explaining the analgesic effect of intrapulpal saline injection with the pressure that it exerts [79].

In regards to the studies that addressed the management of cleft maxillary hypoplasia [41-44] there was only one comparison, distraction osteogenesis versus Le Fort I osteotomy. There were no divergences in the studies conclusions, leading to a possible superiority of distraction osteogenesis over the conventional technique. However, the scientific literature induces us to conclude that the choice between distraction osteogenesis and conventional orthognathic surgery is dependent on advancement length. Baek et al. published a controlled clinical trial comparing these techniques in which they realize this fact [80]. Scolozzi, in a review of 80 scientific articles, concludes that distraction osteogenesis should be applied for displacements larger than $6 \mathrm{~mm}$ in cleft patients [81]. On the other hand, as a meta-analysis on the issue concludes, there is little high-level evidence to safely guide the surgeon in this decision [82].

On the issue "perioperative steroids," both selected articles $[45,46]$ conclude in favor of intravenous dexamethasone sodium phosphate perioperative administration in palatoplasties. Since there is a substantial risk of postoperative airway obstruction after palatoplasties (one of the most common postoperative problems) [83] and other craniofacial surgeries [84], perioperative steroids became a standard practice in many craniofacial centers $[45,84,85]$. However these two RCTs did not report relevant side effects; the samples were too small (45 [45] and 20 [46] patients) to analyze, without a high bias, steroids complications, such as psychosis $[58,59]$ and hypertension [86].

The use of bone substitutes is one way to avoid the morbidities associated with performance of autogenous bone graft in alveoloplasties, and one of the most promising is the bone morphogenetic protein-2 (BMP-2) [87]. The two RCTs found on alveoloplasties [47, 48] concluded that BMP-2 is superior to the conventional technique, with an increase in bone regeneration and reduced patient morbidity. However, since the samples used were small (16 [48] and 21 [47] patients), we still can not assure its safety in relation to theoretical risks: non-small-cell lung cancer; pancreatic and oral cancer; heterotopic ossification and undesirable bone growth, even in the malignant form [87]. The lack of larger studies has been highlighted by a Cochrane review on the issue [60].
This systematic review found RCTs in favor of the following: rectal acetaminophen $40 \mathrm{mg} / \mathrm{kg}$ administered in the operating room at the end of the palatoplasty, and $30 \mathrm{mg} / \mathrm{kg}$ every 8 hours until 48 hours; bilateral infraorbital nerve block with bupivacaine in children who will undergo cleft lip repair; osteogenesis distraction in the cleft maxillary hypoplasia treatment; intravenous dexamethasone sodium phosphate $0.25 \mathrm{mg} / \mathrm{kg}$ before palatoplasty and every 8 hours (two doses after surgery); alveoloplasty with BMP-2. However, a far from ideal number of non-Dutchcleft RCTs (14 articles) proved to be of high quality, which can be verified by the following parameters [88]: 57.14\% (8/14) explicit the randomization mode; $21.43 \%(3 / 14)$ report allocation concealment; $21.43 \%$ (3/14) made clear how they calculated the sample size. In regards to Dutchcleft studies, all of them explicit in some way the randomization mode and allocation concealment. These high-quality RCTs proved that infant orthopedics with Zurich approach is not recommended to the cleft patient. More collaborations such as Dutchcleft need to be done to safely guide cleft teams around the world, and to decrease the huge variety of practices in this area in the long term.

\section{Conclusion}

Few randomized controlled trials were found approaching cleft treatment, and fewer related to surgical repair of this deformity. From the found articles, only a small percentage reported the study with known quality parameters. However, one consistent conclusion could be verified due to fourteen Ducthcleft RCTs; there is no high-level evidence supporting the use of infant orthopedics by Zurich approach. So there is a need for more multicenter collaborations, mainly on surgical area, to reduce the variety of treatment modalities and to ensure that the cleft patient receives an evidence-based clinical practice.

\section{References}

[1] E. B. Strong and L. M. Buckmiller, "Management of the cleft palate," Facial plastic surgery clinics of North America, vol. 9, no. 1, pp. 15-25, 2001.

[2] M. Miloro, P. Larsen, G. E. Ghali, and P. Waite, Peterson's Principles of Oral and Maxillofacial Surgery, BC Decker, Ontario, Canada, 2 ed edition, 2004.

[3] American Cleft Palate-Craniofacial Association, "Parameters for the evaluation and treatment of patients with cleft lip/ palate or other craniofacial anomalies," Cleft Palate-Craniofacial Journal, vol. 30, supplement 1, p. 4, 1993.

[4] P. A. Mossey, J. Little, R. G. Munger, M. J. Dixon, and W. C. Shaw, "Cleft lip and palate," The Lancet, vol. 374, no. 9703, pp. 1773-1785, 2009.

[5] S. L. Lau and N. Samman, "Evidence-based practice in oral and maxillofacial surgery: audit of 1 training center," Journal of Oral and Maxillofacial Surgery, vol. 65, no. 4, pp. 651-657, 2007.

[6] World Health Organization, "Global strategies to reduce the health-care burden of craniofacial anomalies: report of WHO meetings on International Collaborative Research on Craniofacial Anomalies, Geneva, Switzerland, 5-8 November 2000; 
Park City, Utah, USA, 24-26 May 2001,” Tech. Rep., World Health Organization, Geneva, 2002.

[7] O. Bergland, G. Semb, and F. E. Aabyholm, "Elimination of the residual alveolar cleft by secondary bone grafting and subsequent orthodontic treatment," Cleft Palate Journal, vol. 23, no. 3, pp. 175-205, 1986.

[8] A. P. Betrán, L. Say, A. M. Gülmezoglu, T. Allen, and L. Hampson, "Effectiveness of different databases in identifying studies for systematic reviews: experience from the WHO systematic review of maternal morbidity and mortality," BMC Medical Research Methodology, vol. 5, p. 6, 2005.

[9] D. Shaikh, N. S. Mercer, K. Sohan, P. Kyle, and P. Soothill, "Prenatal diagnosis of cleft lip and palate," British Journal of Plastic Surgery, vol. 54, no. 4, pp. 288-289, 2001.

[10] M. Miloro, P. Larsen, and G. E. Ghali, WaitePeterson's Principles of Oral and Maxillofacial Surgery, BC Decker, Ontario, Canada, 2 edition, 2004.

[11] R. E. Kirschner and D. LaRossa, "Cleft lip and palate," Otolaryngologic Clinics of North America, vol. 33, no. 6, pp. 1191$1215,2000$.

[12] O. A. Arosarena, "Cleft lip and palate," Otolaryngologic Clinics of North America, vol. 40, no. 1, pp. 27-60, 2007.

[13] E. B. Katzel, P. Basile, P. F. Koltz, J. R. Marcus, and J. A. Girotto, "Current surgical practices in cleft care: cleft palate repair techniques and postoperative care," Plastic and Reconstructive Surgery, vol. 124, no. 3, pp. 899-900, 2009.

[14] K. E. Salyer, "Excellence in cleft lip and palate treatment," Journal of Craniofacial Surgery, vol. 12, no. 1, pp. 2-5, 2001.

[15] P. R. Shetye, "Presurgical infant orthopedics," The Journal of Craniofacial Surgery, vol. 23, no. 1, pp. 210-211, 2012.

[16] D. Levy-Bercowski, E. DeLeon Jr, J. W. Stockstill, and J. C. Yu, "Orthognathic cleft-surgical/orthodontic treatment," Seminars in Orthodontics, vol. 17, no. 3, pp. 197-206, 2011.

[17] P. J. Boyne and N. R. Sands, "Secondary bone grafting of residual alveolar and palatal clefts," Journal of Oral Surgery, vol. 30, no. 2, pp. 87-92, 1972.

[18] A. M. Kuijpers-Jagtman, "The orthodontist, an essential partner in CLP treatment," B-ENT, vol. 2, no. 4, pp. 57-62, 2006.

[19] C. C. Vlachos, "Orthodontic treatment for the cleft palate patient," Seminars in Orthodontics, vol. 2, no. 3, pp. 197-204, 1996.

[20] H. Friede and C. Katsaros, "Current knowledge in cleft lip and palate treatment from an orthodontist's point of view," Journal of Orofacial Orthopedics, vol. 59, no. 6, pp. 313-330, 1998.

[21] C. A. M. Bongaarts, B. Prahl-Andersen, E. M. Bronkhorst et al., "Infant orthopedics and facial growth in complete unilateral cleft lip and palate until six years of age (Dutchcleft)," Cleft Palate-Craniofacial Journal, vol. 46, no. 6, pp. 654-663, 2009.

[22] C. A. M. Bongaarts, B. Prahl-Andersen, E. M. Bronkhorst et al., "Effect of infant orthopedics on facial appearance of toddlers with complete unilateral cleft lip and palate (Dutchcleft)," Cleft Palate-Craniofacial Journal, vol. 45, no. 4, pp. 407413, 2008.

[23] C. Prahl, B. Prahl-Andersen, M. A. Van't Hof, and A. M. Kuijpers-Jagtman, "Infant orthopedics and facial appearance: a randomized clinical trial (Dutchcleft)," Cleft PalateCraniofacial Journal, vol. 43, no. 6, pp. 659-664, 2006.

[24] C. Prahl, B. Prahl-Andersen, M. A. Van't Hof, and A. M. Kuijpers-Jagtman, "Presurgical orthopedics and satisfaction in motherhood: a randomized clinical trial (Dutchcleft)," Cleft Palate-Craniofacial Journal, vol. 45, no. 3, pp. 284-288, 2008.

[25] A. G. Masarei, A. Wade, M. Mars, B. C. Sommerlad, and D. Sell, "A randomized control trial investigating the effect of presurgical orthopedics on feeding in infants with cleft lip and/or palate," Cleft Palate-Craniofacial Journal, vol. 44, no. 2, pp. 182-193, 2007.

[26] C. Prahl, A. M. Kuijpers-Jagtman, M. A. Van't Hof, and B. Prahl-Andersen, "Infant orthopedics in UCLP: effect on feeding, weight, and length: a randomized clinical trial (Dutchcleft)," Cleft Palate-Craniofacial Journal, vol. 42, no. 2, pp. 171$177,2005$.

[27] C. A. M. Bongaarts, M. A. Van't Hof, B. Prahl-Andersen, I. V. Dirks, and A. M. Kuijpers-Jagtman, "Infant orthopedics has no effect on maxillary arch dimensions in the deciduous dentition of children with complete unilateral cleft lip and palate (Dutchcleft)," Cleft Palate-Craniofacial Journal, vol. 43, no. 6, pp. 665-672, 2006.

[28] C. A. M. Bongaarts, A. M. Kuijpers-Jagtman, M. A. Van't Hof, and B. Prahl-Andersen, "The effect of infant orthopedics on the occlusion of the deciduous dentition in children with complete unilateral cleft lip and palate (Dutchcleft)," Cleft Palate-Craniofacial Journal, vol. 41, no. 6, pp. 633-641, 2004.

[29] C. Prahl, A. M. K. Jagtman, M. A. V. Hof, and B. P. Andersen, "A randomized prospective clinical trial of the effect of infant orthopedics in unilateral cleft lip and palate: prevention of collapse of the alveolar segments (Dutchcleft)," Cleft PalateCraniofacial Journal, vol. 40, no. 4, pp. 337-342, 2003.

[30] C. Prahl, A. M. Kuijpers-Jagtman, M. A. Van 'T Hof, and B. Prahl-Andersen, "A randomised prospective clinical trial into the effect of infant orthopaedics on maxillary arch dimensions in unilateral cleft lip and palate (Dutchcleft)," European Journal of Oral Sciences, vol. 109, no. 5, pp. 297-305, 2001.

[31] E. M. Konst, T. Rietveld, H. F. M. Peters, and A. M. K. Jagtman, "Language skills of young children with unilateral cleft lip and palate following infant orthopedics: a randomized clinical trial," Cleft Palate-Craniofacial Journal, vol. 40, no. 4, pp. 356362, 2003.

[32] E. M. Konst, H. Weersink-Braks, T. Rietveld, and H. Peters, "An intelligibility assessment of toddlers with cleft lip and palate who received and did not receive presurgical infant orthopedic treatment," Journal of Communication Disorders, vol. 33, no. 6, pp. 483-501, 2000.

[33] E. M. Konst, C. Prahl, H. Weersink-Braks et al., "Costeffectiveness of infant orthopedic treatment regarding speech in patients with complete unilateral cleft lip and palate: a randomized three-center trial in the netherlands (Dutchcleft)," Cleft Palate-Craniofacial Journal, vol. 41, no. 1, pp. 71-77, 2004.

[34] E. M. Konst, T. Rietveld, H. F. M. Peters, and B. P. Andersen, "Phonological development of toddlers with unilateral cleft lip and palate who were treated with and without infant orthopedics: a randomized clinical trial," Cleft Palate-Craniofacial Journal, vol. 40, no. 1, pp. 32-39, 2003.

[35] E. M. Konst, T. Rietveld, H. F. M. Peters, and H. W. Braks, "Use of a perceptual evaluation instrument to assess the effects of infant orthopedics on the speech of toddlers with cleft lip and palate," Cleft Palate-Craniofacial Journal, vol. 40, no. 6, pp. 597-605, 2003.

[36] S. M. Mireskandari and J. Makarem, "Effect of rectal diclofenac and acetaminophen alone and in combination on postoperative pain after cleft palate repair in children," The Journal of Craniofacial Surgery, vol. 22, no. 5, pp. 1955-1959, 2011.

[37] D. H. Bremerich, G. Neidhart, K. Heimann, P. Kessler, and M. Behne, "Prophylactically-administered rectal acetaminophen does not reduce postoperative opioid requirements in infants 
and small children undergoing elective cleft palate repair," Anesthesia and Analgesia, vol. 92, no. 4, pp. 907-912, 2001.

[38] N. Jonnavithula, P. Durga, V. Madduri et al., "Efficacy of palatal block for analgesia following palatoplasty in children with cleft palate," Paediatric Anaesthesia, vol. 20, no. 8, pp. 727-733, 2010.

[39] S. A. Takmaz, H. Y. Uysal, A. Uysal, U. Kocer, B. Dikmen, and B. Baltaci, "Bilateral extraoral, infraorbital nerve block for postoperative pain relief after cleft lip repair in pediatric patients: a randomized, double-blind controlled study," Annals of Plastic Surgery, vol. 63, no. 1, pp. 59-62, 2009.

[40] H. F. Nicodemus, M. J. R. Ferrer, V. C. Cristobal, and L. De Castro, "Bilateral infraorbital block with $0.5 \%$ bupivacaine as post-operative analgesia following cheiloplasty in children," Scandinavian Journal of Plastic and Reconstructive Surgery and Hand Surgery, vol. 25, no. 3, pp. 253-257, 1991.

[41] H. D. P. Chua, T. L. Whitehill, N. Samman, and L. K. Cheung, "Maxillary distraction versus orthognathic surgery in cleft lip and palate patients: effects on speech and velopharyngeal function," International Journal of Oral and Maxillofacial Surgery, vol. 39, no. 7, pp. 633-640, 2010.

[42] N. Chanchareonsook, T. L. Whitehill, and N. Samman, "Speech outcome and velopharyngeal function in cleft palate: comparison of Le Fort I maxillary osteotomy and distraction osteogenesis-early results," Cleft Palate-Craniofacial Journal, vol. 44, no. 1, pp. 23-32, 2007.

[43] L. K. Cheung, H. D. P. Chua, and M. B. Hägg, "Cleft maxillary distraction versus orthognathic surgery: clinical morbidities and surgical relapse," Plastic and Reconstructive Surgery, vol. 118, no. 4, pp. 996-1008, 2006.

[44] H. D. P. Chua, M. B. Hgg, and L. K. Cheung, "Cleft maxillary distraction versus orthognathic surgery-which one is more stable in 5 years?" Oral Surgery, Oral Medicine, Oral Pathology, Oral Radiology and Endodontology, vol. 109, no. 6, pp. 803814, 2010.

[45] C. W. Senders, S. M. Di Mauro, H. A. Brodie, B. E. Emery, and J. M. Sykes, "The efficacy of perioperative steroid therapy in pediatric primary palatoplasty," Cleft Palate-Craniofacial Journal, vol. 36, no. 4, pp. 340-344, 1999.

[46] C. W. Senders, B. E. Emery, J. M. Sykes, and H. A. Brodie, "A prospective, double-blind, randomized study of the effects of perioperative steroids on palatoplasty patients," Archives of Otolaryngology-Head and Neck Surgery, vol. 122, no. 3, pp. 267-270, 1996.

[47] N. Alonso, D. Y. S. Tanikawa, R. D. S. Freitas, L. Canan Jr, T. O. Ozawa, and D. L. Rocha, "Evaluation of maxillary alveolar reconstruction using a resorbable collagen sponge with recombinant human bone morphogenetic protein-2 in cleft lip and palate patients," Tissue Engineering C, vol. 16, no. 5, pp. 1183-1189, 2010.

[48] B. P. Dickinson, R. K. Ashley, K. L. Wasson et al., "Reduced morbidity and improved healing with bone morphogenic protein-2 in older patients with alveolar cleft defects," Plastic and Reconstructive Surgery, vol. 121, no. 1, pp. 209-217, 2008.

[49] J. Y. Liau, A. M. Sadove, and J. A. V. Aalst, "An evidence-based approach to cleft palate repair," Plastic and Reconstructive Surgery, vol. 126, no. 6, pp. 2216-2221, 2010.

[50] K. Slim, "Limits of evidence-based surgery," World Journal of Surgery, vol. 29, no. 5, pp. 606-609, 2005.

[51] V. Karri, "Randomised clinical trials in plastic surgery: survey of output and quality of reporting," Journal of Plastic, Reconstructive and Aesthetic Surgery, vol. 59, no. 8, pp. 787-796, 2006.
[52] C. M. McCarthy, E. D. Collins, and A. L. Pusic, "Where do we find the best evidence?" Plastic and Reconstructive Surgery, vol. 122, no. 6, pp. 1942-1947, 2008.

[53] J. C. Winters and D. J. Hurwitz, "Presurgical orthopedics in the surgical management of unilateral cleft lip and palate," Plastic and Reconstructive Surgery, vol. 95, no. 4, pp. 755-764, 1995.

[54] P. R. Shetye, "Presurgical infant orthopedics," Journal of Craniofacial Surgery, vol. 23, no. 1, pp. 210-211, 2012.

[55] N. L. Schechter, C. B. Berde, and M. Yaster, Pain in Infants, Children and Adolescents, Williams and Wilkins, Baltimore, Canada, 1993.

[56] J. C. Posnick and P. Ricalde, "Cleft-orthognathic surgery," Clinics in Plastic Surgery, vol. 31, no. 2, pp. 315-330, 2004.

[57] S. R. Cohen, F. D. Burstein, M. B. Stewart, and M. A. Rathburn, "Maxillary-midface distraction in children with cleft lip and palate: a preliminary report," Plastic and Reconstructive Surgery, vol. 99, no. 5, pp. 1421-1428, 1997.

[58] D. M. Galen, M. Beck, and D. Buchbinder, "Steroid psychosis after orthognathic surgery: a case report," Journal of Oral and Maxillofacial Surgery, vol. 55, no. 3, pp. 294-297, 1997.

[59] P. T. D’Orban, “Steroid-induced psychosis," The Lancet, vol. 2, no. 8664, p. $694,1989$.

[60] J. Guo, Q. Zhang, S. Zou et al., "Secondary bone grafting for alveolar cleft in children with cleft lip or cleft lip and palate," Cochrane Database of Systematic Reviews, no. 4, Article ID CD008050, 2009.

[61] K. Slim, "Limits of evidence-based surgery," World Journal of Surgery, vol. 29, no. 5, pp. 606-609, 2005.

[62] M. M. Cohen Jr and A. Bankier, "Syndrome delineation involving orofacial clefting," Cleft Palate Journal, vol. 28, no. 1, pp. 119-120, 1991.

[63] J. Milerad, O. Larson, C. Hagberg, and M. Ideberg, "Associated malformations in infants with cleft lip and palate: a prospective, population-based study," Pediatrics, vol. 100, no. 2, pp. 180-186, 1997.

[64] S. L. Clark, J. F. Teichgraeber, R. G. Fleshman et al., "Longterm treatment outcome of presurgical nasoalveolar molding in patients with unilateral cleft lip and palate," Journal of Craniofacial Surgery, vol. 22, no. 1, pp. 333-336, 2011.

[65] P. G. Patil, S. P. Patil, and S. Sarin, "Nasoalveolar molding and long-term postsurgical esthetics for unilateral cleft lip/palate: 5-year follow-up," Journal of Prosthodontics, vol. 20, no. 7, pp. 577-582, 2011.

[66] C. T. H. Lee, J. S. Garfinkle, S. M. Warren, L. E. Brecht, C. B. Cutting, and B. H. Grayson, "Nasoalveolar molding improves appearance of children with bilateral cleft lip-cleft palate," Plastic and Reconstructive Surgery, vol. 122, no. 4, pp. 11311137, 2008.

[67] I. Barillas, W. Dec, S. M. Warren, C. B. Cutting, and B. H. Grayson, "Nasoalveolar molding improves long-term nasal symmetry in complete unilateral cleft lip-cleft palate patients," Plastic and Reconstructive Surgery, vol. 123, no. 3, pp. 10021006, 2009.

[68] C. D. van der Marel, R. A. Van Lingen, M. A. L. Pluim et al., "Analgesic efficacy of rectal versus oral acetaminophen in children after major craniofacial surgery," Clinical Pharmacology and Therapeutics, vol. 70, no. 1, pp. 82-90, 2001.

[69] B. J. Anderson and N. H. G. Holford, "Rectal paracetamol dosing regimens: determination by computer simulation," Paediatric Anaesthesia, vol. 7, no. 6, pp. 451-455, 1997.

[70] P. K. Birmingham, M. J. Tobin, T. K. Henthorn et al., “Twentyfour-hour pharmacokinetics of rectal acetaminophen in children: an old drug with new recommendations," Anesthesiology, vol. 87 , no. 2, pp. 244-252, 1997. 
[71] K. P. K. Prabhu, J. Wig, and S. Grewal, "Bilateral infraorbital nerve block is superior to peri-incisional infiltration for analgesia after repair of cleft lip," Scandinavian Journal of Plastic and Reconstructive Surgery and Hand Surgery, vol. 33, no. 1, pp. 83-87, 1999.

[72] D. J. Steward, "Anesthesia for patients with cleft lip and palate," Seminars in Anesthesia, Perioperative Medicine and Pain, vol. 26, no. 3, pp. 126-132, 2007.

[73] S. M. Fenlon, "Anaesthesia for plastic surgery in children," Current Anaesthesia and Critical Care, vol. 13, no. 2, pp. 8791, 2002.

[74] L. Bouattour, M. Smaoui, S. Belhaj, K. Khemakhem, and H. Chikhrouhou, "Infraorbital nerve block for cleft lip surgery," Anesthesiology, vol. 24, p. 100, 2007.

[75] E. R. Mariano, D. Watson, V. J. Loland et al., "Bilateral infraorbital nerve blocks decrease postoperative pain but do not reduce time to discharge following outpatient nasal surgery," Canadian Journal of Anesthesia, vol. 56, no. 8, pp. 584-589, 2009.

[76] D. A. Markakis, "Regional anesthesia in pediatrics," Anesthesiology Clinics of North America, vol. 18, no. 2, pp. 355-381, 2000.

[77] M. R. Kamath, S. G. Mehandale, and U. S. Raveendra, "Comparative study of greater palatine nerve block and intravenous pethidine for postoperative analgesia in children undergoing palatoplasty," Indian Journal of Anaesthesia, vol. 53, no. 6, pp. 654-661, 2009.

[78] K. Gupta, P. K. Gupta, P. Bansal, and S. K. Tyagi, "Anesthetic management for Smile Train a blessing for population of low socioeconomic status: a prospective study," Anesthesia, vol. 4, no. 2, pp. 81-84, 2010.

[79] J. Vangheluwe and R. Walton, "Intrapulpal injection: factors related to effectiveness," Oral Surgery, Oral Medicine, Oral Pathology, Oral Radiology, and Endodontics, vol. 83, no. 1, pp. 38-40, 1997.

[80] S. H. Baek, J. K. Lee, J. H. Lee, M. J. Kim, and J. R. Kim, "Comparison of treatment outcome and stability between distraction osteogenesis and LeFort I osteotomy in cleft patients with maxillary hypoplasia," Journal of Craniofacial Surgery, vol. 18, no. 5, pp. 1209-1215, 2007.

[81] P. Scolozzi, "Distraction osteogenesis in the management of severe maxillary hypoplasia in cleft lip and palate patients," Journal of Craniofacial Surgery, vol. 19, no. 5, pp. 1199-1214, 2008.

[82] L. K. Cheung and H. D. P. Chua, "A meta-analysis of cleft maxillary osteotomy and distraction osteogenesis," International Journal of Oral and Maxillofacial Surgery, vol. 35, no. 1, pp. 14-24, 2006.

[83] A. T. Bösenberg, "Anaesthesia for cleft lip and palate surgery," Southern African Journal of Anaesthesia and Analgesia, vol. 13, no. 14, pp. 9-14, 2007.

[84] C. R. Weber and J. M. Griffin, "Evaluation of dexamethasone for reducing postoperative edema and inflammatory response after orthognathic surgery," Journal of Oral and Maxillofacial Surgery, vol. 52, no. 1, pp. 35-39, 1994.

[85] C. F. Santos, A. M. Calvo, V. T. Sakai et al., "The changing pattern of analgesic and anti-inflammatory drug use in cleft lip and palate repair," Oral Surgery, Oral Medicine, Oral Pathology, Oral Radiology and Endodontology, vol. 102, no. 4, pp. e16e20, 2006.

[86] D. V. Lardizabal and A. A. Roxas, "Dexamethasone as adjunctive therapy in adult patients with probable $\mathrm{TB}$ meningitis stage II and stage III: an open randomised controlled trial," Philippines Journal of Neurology, vol. 4, pp. 4-10, 1998.
[87] D. M. Smith, G. M. Cooper, M. P. Mooney, K. G. Marra, and J. E. Losee, "Bone morphogenetic protein 2 therapy for craniofacial surgery," Journal of Craniofacial Surgery, vol. 19, no. 5, pp. 1244-1259, 2008.

[88] P. A. Kyzas, "Evidence-based oral and maxillofacial surgery," Journal of Oral and Maxillofacial Surgery, vol. 66, no. 5, pp. 973-986, 2008. 


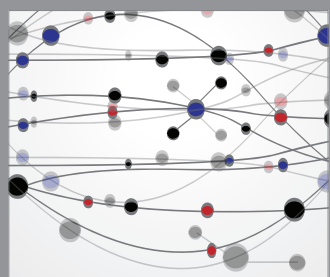

The Scientific World Journal
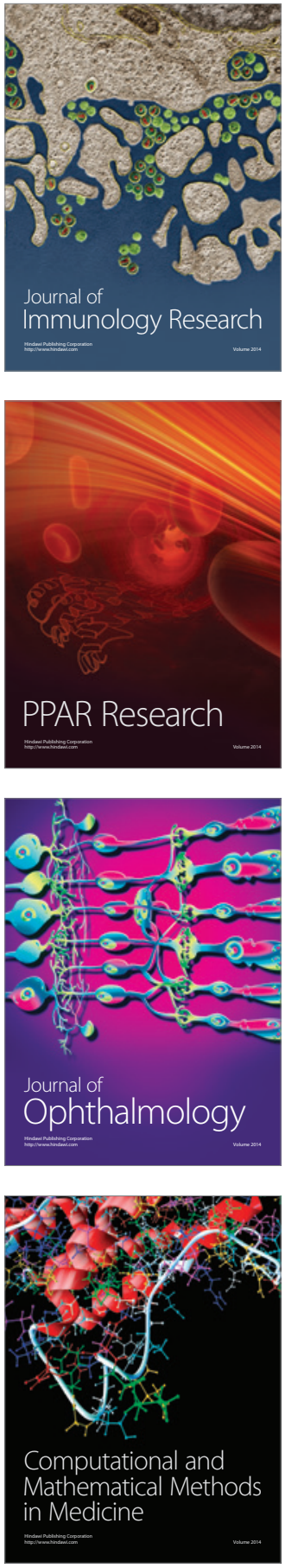

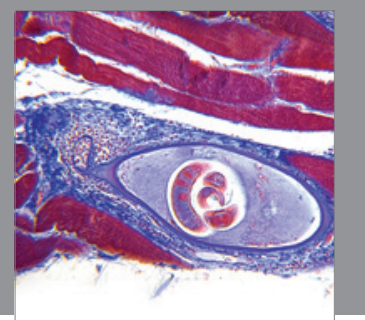

Gastroenterology

Research and Practice
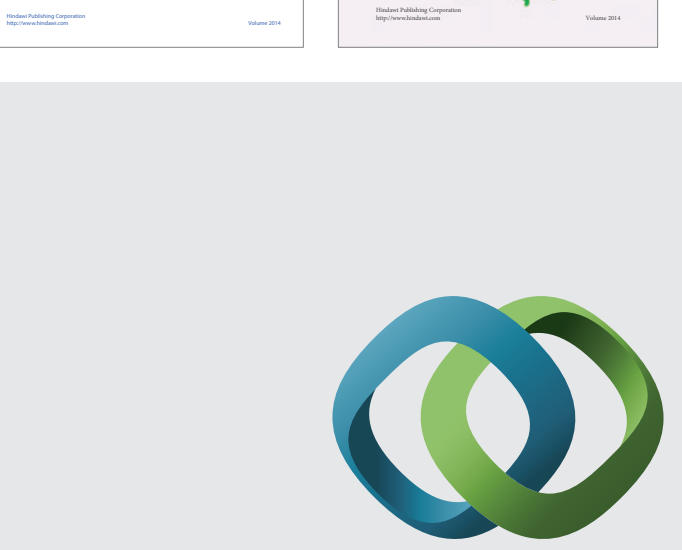

\section{Hindawi}

Submit your manuscripts at

http://www.hindawi.com
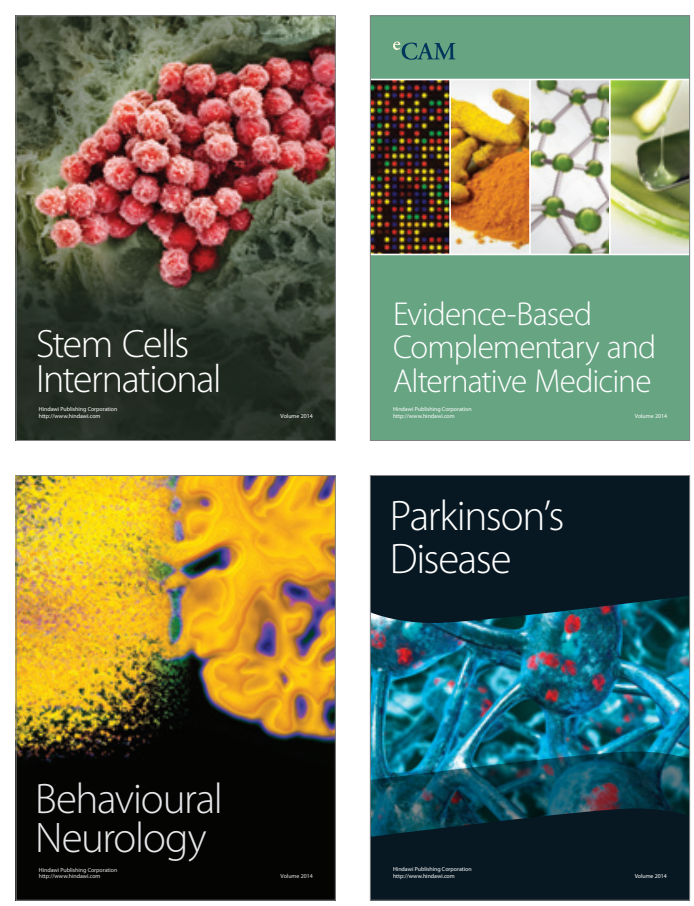

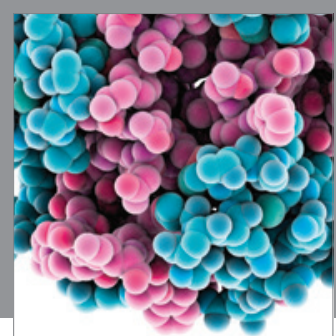

Journal of
Diabetes Research

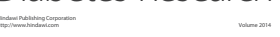

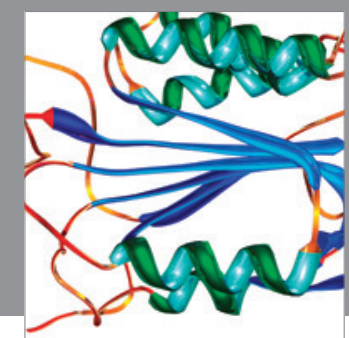

Disease Markers
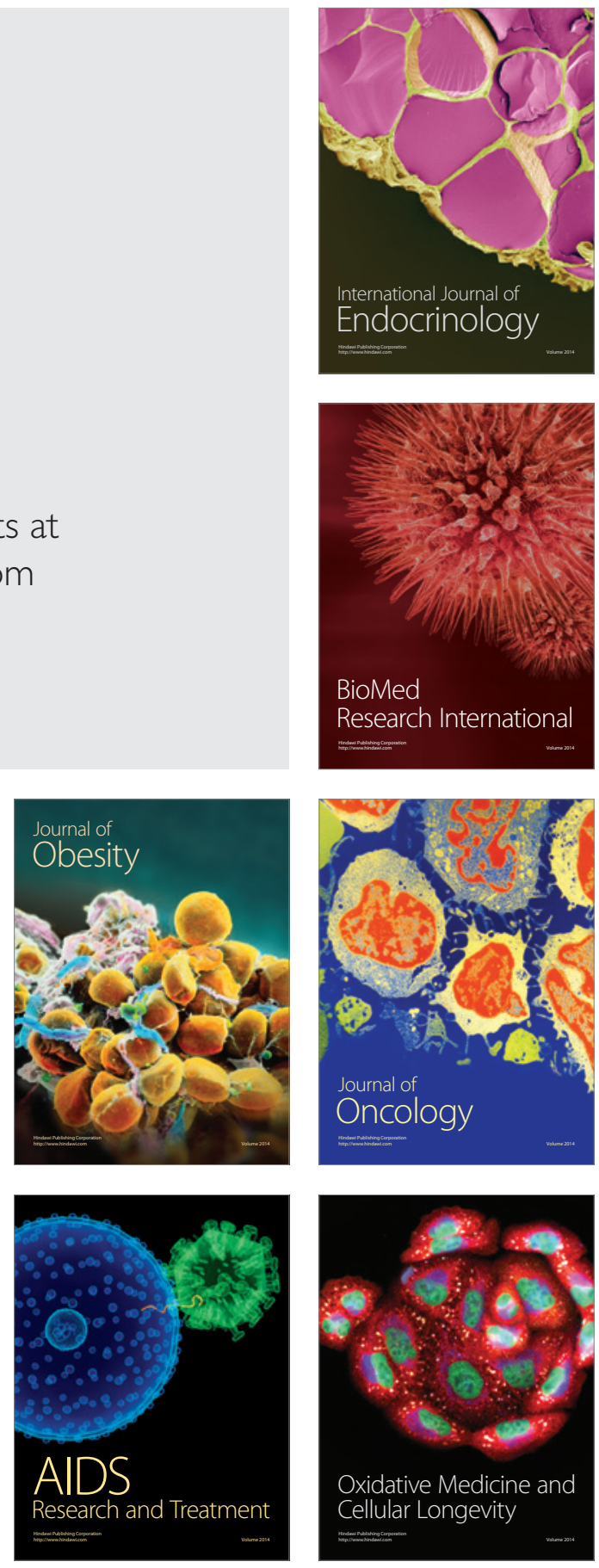